\title{
Peningkatan Karakter Religius Peserta Didik Melalui Pembiasaan Membaca Asma'ul Husna Di SMPN 1 Ngoro Jombang
}

\author{
Nurul Lailiyah \\ nurulstituw@gmail.com \\ Prodi PAI STIT Al-Urwatul Wutsqo Jombang \\ Rofiqotul Hasanah \\ Prodi PAI STIT Al-Urwatul Wutsqo Jombang
}

\begin{abstract}
This study is intended to describe the teacher role in improving students' religious character through the reading habit of Asmaul Husna at SMPN 1 Ngoro Jombang, 2. Describing students' religious character of SMPN 1 Ngoro Jombang. This research uses qualitative approach. The data collection is done through interviews, observation and documentation. The data then analyzed by reduction, display and verification data. The results show that: 1 . the teachers' role in implementing students' religious character education through Asmaul Husna reading habit at SMPN 1 Ngoro Jombang, are teachers as: role model, motivator, dynamic, evaluator. 2 . The religious character of students at SMPN 1 Ngoro Jombang: a. Character values formed in SMPN 1 Ngoro Jombang: 1). Religious 2). Discipline 3). Responsibility 4). Tolerance 5). Nobel character 6). Diligent 7). Independent. $\mathrm{b}$. The implementation of the Asmaul Husna reading habit by using such methods as: 1). Getting used to: a).hands shaking with the teacher b) lining up in front of the classroom c). Praying before the activity started. 2) Discipline 3) modelling.
\end{abstract}

Keywords: religious character, asmaul husna

\section{Pendahuluan}

Peserta didik adalah sesorang yang sedang mengalami pertumbuhan dan juga perkembangan baik secara fisik maupun psikis secara fitrahnya. Sehingga dalam prosesnya setiap individu memerlukan bimbingan dan juga pengarahan secara terus menerus atau konsisten untuk menghasilkan sesuatu yang maksimal. ${ }^{1}$ Sedangkan dalam proses pendidikan, peserta didik merupakan salah satu komponen manusiawi yang menempati posisi sentral. Peserta didik menjadi pokok persoalan dan tumpuan perhatian dalam semua proses transformasi yang disebut pendidikan.

Dalam Undang-Undang Sistem Pendidikan Nasional No 20 tahun 2003 bahwa pendidikan adalah usaha sadar dan terencana untuk mewujudkan suasana

\footnotetext{
${ }^{1}$ Desmita. Psikologi Perkembangan Peserta Didik. (Bandung: PT. Remaja Rosdakarya, 2012), 39.
} 
belajar dan proses pembelajaran agar peserta didik secara aktif mengembangkan potensi dirinya untuk memiliki kekuatan spiritual keagamaan, pengendalian diri, kepribadian, kecerdasan, akhlak mulia, serta keterampilan yang diperlukan dirinya, masyarakat, bangsa dan negara. ${ }^{2}$

Pendidikan karakter berlandaskan pada karakter dasar manusia itu sendiri yang bersumber pada nilai moral universal (bersifat absolut) yang bersumber dari agama yang juga disebut golden rule. Pendidikan karakter memiliki tujuan yang pasti, apabila berpijak pada nilai-nilai karakter dasar tersebut. Menurut para ahli psikologi, beberapa nilai karakter dasar tersebut antara lain cinta kepada Allah SWT dan ciptaan-Nya (alam dengan isinya), tanggung jawab, jujur, hormat dan santun, kasih sayang, peduli dan kerja sama, percaya diri, kreatif, kerja keras dan pantang menyerah, keadilan dan kepemimpinan, baik dan rendah hati, toleransi, cinta damai serta cinta persatuan. Penyelenggaraan pendidikan karakter di sekolah harus berpijak pada nilai-nilai karakter dasar manusia. Selanjutnya, dikembangkan menjadi nilai-nilai yang lebih banyak atau tinggi (yang bersifat tidak absolut, relatif) sesuai kebutuhan, kondisi, dan lingkungan sekolah itu sendiri. ${ }^{3}$

Pendidikan karakter juga dapat dimaknai sebagai suatu sistem penanaman nilai-nilai karakter kepada warga sekolah yang meliputi komponen pengetahuan, kesadaran atau kemauan, dan tindakan untuk melaksanakan nilai-nilai tersebut baik terhadap Tuhan Yang Maha Esa, diri sendiri, sesama, lingkungan, maupun kebangsaan sehingga menjadi manusia insan kamil. Penanaman nilai kepada warga sekolah maknanya bahwa pendidikan karakter baru akan efektif jika tidak hanya siswa, tetapi juga para guru, kepala sekolah dan tenaga non-pendidik di sekolah semua harus terlibat dalam pendidikan karakter. ${ }^{4}$ Pendidikan di sekolah terutama pendidikan agama mempunyai peranan yang sangat besar dalam pembentukan karakter religius seseorang. Hal ini sesuai dengan tujuan pendidikan nasional yang tercantum dalam Undang-Undang No 2 Tahun 1989 yang menyatakan bahwa sasaran yang ingin dicapai dari pendidikan agama adalah membentuk manusia beriman dan bertaqwa kepada Allah SWT, berbudi pekerti luhur, berkepribadian, disiplin, bekerja keras, tanggung jawab, mandiri, terampil, sehat jasmani dan rohani (Undang-Undang Nomor 2 Tahun 1989).

Dalam ajaran agama, misalnya islam maka yang terpenting adalah akhlak (moral).Salah satu misi penting yang diemban Rasulullah yaitu untuk menyempurnakan akhlak masyarakat yang telah rusak. Dengan penuh kesabaran

2 Undang-Undang RI No. 20 Tahun 2003 tentang Sistem Pendidikan Nasional

3 Salahudin Anas, dan Irwanto A. PendidikanKarakter Berbasis Agama dan Budaya Bangsa. (Bandung: Pustaka Setia, 2013), 33.

${ }^{4}$ M., Samani \& Hariyanto. .Konsep dan Model Pendidikan Karakter. (Bandung: Remaja Rosdakarya, 2017), 46. 
beliau mampu mengubah akhlak masyarakat yang telah rusak menjadi masyarakat yang berakhlakul karimah. Pentingnya akhlak adalah untuk memberikan bimbingan moral. Diantara akhlak mulia yang tercermin dalam sifatsifat kerasulan yang ada pada pribadi Rasulullah SAW seperti sifat siddiq, amanah, tabligh, fathanah. Sebagaimana firman Allah:

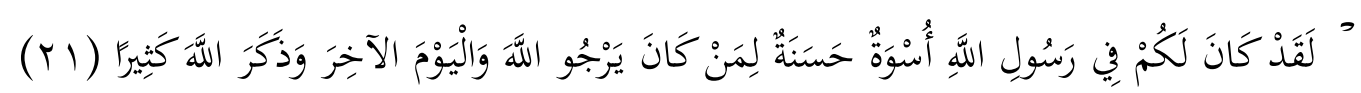

Artinya: Sesungguhnya telah ada pada (diri) Rasulullah itu suri teladan yang baik bagimu (yaitu) bagi orang yang mengharap (rahmat) Allah dan (kedatangan) hari kiamat dan yang banyak menyebut Allah. (Q.S Al Ahzab: 21) 5

Serta sabda Nabi:

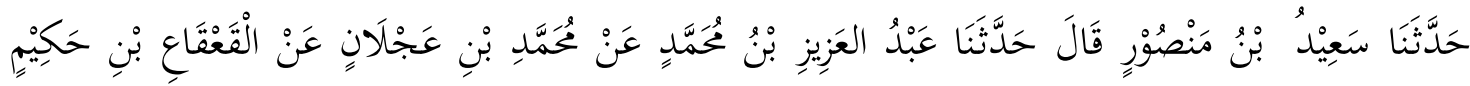

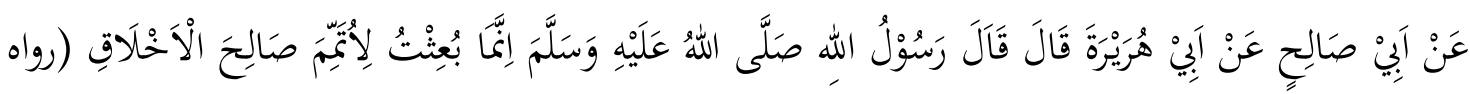

Artinya: Telah menceritakan kepada kami Sa'id bin Manshur berkata: telah menceritakan kepada kami Abdul Aziz bin Muhammad dari Muhammad bin 'Ajlan dari Al Qa'qa' bin Hakim dari Abu Hurairah berkata: Rasulullah SAW bersabda:"Bahwasannya aku diutus untuk menyempurnakan akhlak yang baik"(HR. Ahmad).

Dari hadits dan penggalan ayat diatas beliau memberikan contoh akhlak yang mulia. Diantara akhlak beliau yang mulia yaitu : jujur, amanah, cerdas dan dapat dipercaya. Dalam proses pembelajaran, guru merupakan unsur manusiawi yang menempati posisi dan memegang peranan penting karena guru tidak hanya bertugas sebagai pengajar, tetapi juga berperan dalam usaha pembentukan watak, tabiat maupun pengembangan sumber daya yang dimiliki oleh anak didik. Guru tidak hanya berperan sebagai pengajar yang hanya memindahkan pengetahuan dan menyalurkan nilai-nilai yaitu nilai-nilai untuk pembentukan akhlak atau perilaku anak didik. ${ }^{6}$ Sedangkan dalam agama islam, guru menempati kedudukan yang sangat mulia. Guru tidak hanya bertugas sebagai pengajar, namun juga bertugas membentuk anak didik menjadi insanul kamil (manusia yang sempurna) sebagai khalifah yang mulia diatas bumi ini, oleh karena itu guru disamping ditutut untuk memiliki keahlian khusus, ia juga harus mengedepankan moral dan etika dalam berinteraksi dengan anak didiknya agar ia dapat menjadi contoh dan teladan untuk anak didiknya.

\footnotetext{
${ }^{5}$ QS. Al Ahzab, 21.

6 A.M. Sardiman, .Interaksi dan Motivasi Belajar Mengajar, (Jakarta: PT Raja Grafindo Persada. 2008), 125.
} 
Guru merupakan faktor penting yang besar pengaruhnya terhadap keberhasilan pendidikan karakter di sekolah, bahkan sangat menentukan berhasil tidaknya peserta didik dalam mengembangkan pribadinya secara utuh. Dikatakan demikian, karena guru merupakan figur utama, serta contoh dan teladan bagi peserta didik. Oleh karena itu, dalam pendidikan karakter guru harus mulai dari dirinya sendiri agar apa-apa yang dilakukannya dengan baik menjadi baik pula pengaruhnya terhadap peserta didik. ${ }^{7}$ Dalam implementasi pendidikan karakter, kualitas guru dapat ditinjau dari dua segi, yaitu segi proses dan segi hasil. Dari segi proses guru guru di katakan berhasil apabila mampu melibatkan sebagian besar peserta didik secara aktif, khususnya mental, dan sosial dalam proses pendidikan karakter di sekolah. Di samping itu, dapat dilihay dari gairah dan semangatnya dalam melaksanakan pendidikan karakter di sekolah serta adanya rasa percaya diri. Sementara itu, dari segi hasil, guru dikatakan berhasil apabila pendidikan karakter yang dilaksanakan mampu mengadakan perubahan karakter pada sebagian besar peserta didik kearah yang lebih baik. ${ }^{8}$

Melihat pentingnya karakter religius yang sewajarnya diciptakan dengan suasana religius melalui tradisi, perilaku, pembiasaan yang kontinu dan konsisten, namun dalam lembaga pendidikan semua tidak lepas dari suatu pengawasan, pemantauan dan pembinaan yang dilakukan oleh pihak yang terkait disekolah. SMPN 1 Ngoro Jombang adalah sekolah negeri yang tidak berlatar belakang madrasah namun dalam pelaksanaannya tidak hanya terfokuskan pada pembelajaran formal saja tetapi juga pada pendidikan karakter terutama karakter religius. SMPN 1 Ngoro Jombang memiliki visiyaitu beriman, berkarya dan berprestasi, untuk mewujudkan visi SMPN 1 Ngoro Jombang mengadakan beberapa program yang berbasis madrasah seperti kegiatan pembiasaan membaca asma'ul husna, pembiasaan membaca al-Qur'an, pembiasaan membaca istighosah di hari jum'at, sholat dluha berjama'ah dan menghafal tahlil yang bertujuan untuk meningkatkan kualitas karakter religius peserta didik yang berasal dari latar belakang yang berbeda.

Berkaitan dengan penelitian ini peneliti lebih memfokuskan pada program pembiasaan membaca asma'ul husna dimana dalam program tersebut diharapkan peserta didik bukan hanya sekedar membaca melainkan hafal dan faham akan asma'ul husna serta mampu menerapkan pembiasaan membaca asma'ul husna dalam kegiatan-kegiatan yang ada di masyarakat luas. Kemudian dalam program ini guru juga berperan untuk mampu meningkatkan karakter religius pada anak yang datang dari berbagai latar belakang dan berbeda-beda karakter terutama

\footnotetext{
${ }^{7}$ Mulyasa, Manajemen Pendidikan Karakter. (Jakarta: Bumi Aksara, 2018), 63.

${ }^{8}$ Mulyasa, Manajemen..., 65.
} 
karakter religiusnya. Pembiasaan diri memiliki arti penting dalam proses pendidikan dan kebiasaan menjadi kunci kesuksesan. Adanya program ini bertujuan untuk membentuk karakter religius peserta didik dan menumbuhkan akhlakul karimah pada peserta didik.

\section{Hasil Penelitian dan Pembahasan}

\section{Peran Guru Dalam Meningkatkan Karakter Religius Peserta Didik Melalui Pembiasaan Membaca Asma'ul Husna}

Peran guru dalam lingkungan SMPN 1 Ngoro sangat memiliki peran yang penting di dalam meningkatkan nilai-nilai karakter religius kepada peserta didik, mengingat guru adalah orangtua kedua yang dipercaya setelah orangtua dalam mendidik dan membimbing anak. Guru memiliki peran dalam proses pembelajaran sebagai pendidik, pengajar dan pelatih. Guru dikatakan sebagai pendidik karena dia telah menyajikan tugas kependidikan sebagaimana tugas orangtua. Guru adalah orang yang memiliki pengetahuan luas dan keahlian dalam pengetahuan. Sehingga guru dituntut untuk memiliki tanggung jawab dalam mendidik peserta didik secara sempurna meliputi pendidikan jasmani, akal dan juga akhlak. Dalam hal ini tugas guru bukan hanya mengajar dan memberikan materi kepada peserta didik, tetapi lebih dari itu yakni membina karakter peserta didik yang datang dari latar belakang yang berbeda-beda sehingga tercapailah kepribadian yang baik. Diantara karakter tersebut adalah karakter tanggung jawab, berakhlakul karimah dan religius.

Berdasarkan hasil wawancara dengan wakil kepala sekolah tersebut dapat disimpulkan bahwa pendidikan karakter sangat penting diterapkan sejak dini karena pendidikan karakter dapat menjadikan seseorang menjadi lebih baik. Pada dasarnya pendidikan karakter dapat dibentuk dari lingkungan sekolah saja tetapi dapat dibentuk dari lingkungan keluarga dan juga masyarakat.

Pendidik dalam pendidikan islam pada hakikatnya adalah orang yang bertanggungjawab terhadap perkembangan peserta didik dengan mengupayakan seluruh potensi dan kecenderungan yang ada pada peserta didik, baik yang cukup ranah efektif, kognitif, maupun psikomotorik. Pendidikan islam menggunakan tujuan sebagai dasar untuk menentukan pengertian pendidik, disebabkan karena pendidikan merupakan kewajiban agama, dan kewajiban hanya dipikulkan kepada orang yang telah dewasa. Kewajiban itu pertama-tama bersifat personal, dalam arti bahwa setiap orang bertanggungjawab atas pendidikan dirinya sendiri, kemudian meningkat pada 
dataran sosial yang berarti bahwa setiap orang bertanggungjawab atas pendidikan orang lain. ${ }^{9}$ Hal ini sesuai dengan firman Allah:

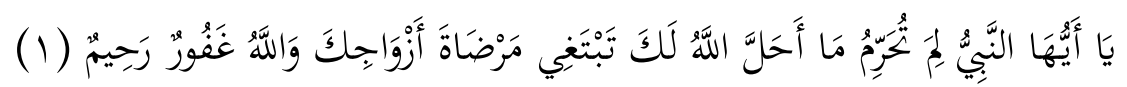

Artinya: "Hai orang-orang yang beriman, peliharalah dirimu dan keluargamu dari api neraka. (Q.S Al-Tahrim: 6). ${ }^{10}$

Guru adalah figur inspirator dan motivator murid dalam mengukir masa depannya. Jika guru mampu menjadi sumber inspirasi dan motivasi bagi anak didiknya, maka hal itu akan menjadi kekuatan anak dalam mengejar cita-cita besarnya di masa depan. Peran guru sangat vital bagi pembentukan kepribadian, cita-cita dan visi misi yang menjadi impian hidup anak didiknya di masa depan. Dibalik kesuksesan murid, selalu ada guru yang memberikan inspirasi dan motivasi besar pada dirinya sebagai stamina dan energi untuk selalu belajar dan bergerak mengejar ketinggalan, menggapai kemajuan, menorehkan prestasi spektakuler dan prestisius dalam panggung sejarah kehidupan manusia. ${ }^{11}$ Menurut Jamal Ma'mur Asmani bahwa peran guru dalam pendidikan karakter meliputi: teladan, inspirator, motivator, dinamisator, dan evaluator ${ }^{12}$

Peran-peran yang sudah di sebutkan di atas, peran guru terlihat jelas saat pelaksanaan program-program di sekolah, dimana guru berperan sebagai teladan, motivator, dinamisator, dan evaluator.

1) Teladan

Guru merupakan sosok yang menjadi cerminan dan teladan bagi peserta didiknya. Seorang guru harus terlebih dahulu memberikan contoh yang baik bagi peserta didiknya misalnya berangkat ke sekolah tepat waktu, berpenampilan rapih, bertutur kata yang sopan, mengikuti programprogram sekolah, sholat duha berjama'ah, mengikuti pembiasaan membaca asma'ul husna dan bertoleransi antar umat beragama.

Mengingat bahwa pentingnya pendidikan karakter menekankan pada aspek sikap, nilai, dan watak peserta didik, maka dalam pembentukannya harus dimulai dari gurunya. Dalam hal ini,bagaimana setiap lembaga pendidikan, baik formal maupun non formal dapat mewujudkan guru yang dapat digugu dan ditiru. Hal ini perlu ditekankan di sini, karena akhir-akhir ini banyak guru yang kehilangan semangat pengabdiannya. Meskipun sudah di sertifikasi, gajinya dinaikan, ditambah

\footnotetext{
${ }^{9}$ N. A. Wiyani, Pendidikan Karakter Berbasis Iman dan Taqwa. (Yogyakarta: Penerbit Teras, 2011), $92-$ 93.

10 Q.S Al-Tahrim: 6

11 Asmani Hawi, Kompetensi Guru Pendidikan Agama Islam. (Jakarta: Rajawali Pers, 2014), 17-18.

12 Asmani, Kompetensi Guru, 71-84.
} 
berbagai tunjangan, ternyata belum mampu mewujudkan guru yang dapat digugu dan ditiru, bahkan sebaliknya sedikit sekali guru yang terjebak dalam tatanan pragmatik materialistik. Selain itu, pendidikan karakter di sekolah pelu ditunjang oleh support system yang memadai, yang dapat mendorong tumbuh dan berkembangnya keshalehan peserta didik. Banyak guru mencita-citakan agar peserta didiknya menjadi generasi yang shaleh, namun kurang didukung oleh support system yang bisa menumbuh kembangkan keshalehan ini. Mislanya peserta didik diharapkan rajin beribadah, berakhlak mulia tetapi guru tidak mencontohkan dirinya sosok yang rajin beribadah. Kondisi tersebut tentu saja menyulitkan peserta didik untuk membentuk karakter yang shaleh. ${ }^{13}$

Keteladanan merupakan faktor mutlak yang harus dimiliki oleh guru. Dalam pendidikan karakter, keteladanan yang dibutuhkan oleh guru berupa konsistensi dalam menjalankan perintah agama dan menjauhi larangan-larangannya, Kepedulian terhadap nasib orang-orang tidak mampu, Kegigihan dalam meraih prestasi secara individu dan sosial, ketahanan dalam menghadapi tantangan, rintangan, dan godaan serta kecepatan dalam bergerak dan beraktualisasi. Selain itu, dibutuhkan pula kecerdasan guru dalam membaca, memanfaatkan dan mengembangkan peluang secara produktif dan kompetitif. Keteladanan guru sangat penting demi efektivitas pendidikan karakter. Tanpa keteladanan, pendidikan karakter kehilangan ruhnya yang paling esensial. Hanya slogan, kamuflase, fatamorgana dan kata-kata negatif lainnya. ${ }^{14}$

2) Motivator

Peran guru sebagai motivator yaitu memberikan motivasi terhadap peserta didik untuk lebih rajin dan semangat dalam belajar terutama dalam belajar agama. Memotivasi agar peserta didik lebih disiplin, aktif dalam mengikuti kegiatan keagamaan terlebih memotivasi agar giat dalam beribadah.

Jamal ma'mur asmuni mengatakan peran guru selanjutnya adalah motivator. Hal ini dapat dilihat dengan adanya kemampuan guru dalam membangkitkan spirit, etos kerja dan potensi yang luar biasa dalam diri peserta didik. Setiap anak adalah genius, yang mempunyai bakar spesifik dan berbeda dengan oranglain. Maka, tugas guru adalah melahirkan potensi itu ke permukaan dengan banyak berlatih, mengasah kemampuan dan mengembangkan potensi semaksimal mungkin. Salah satu upaya yang

${ }_{13}^{13}$ Mulyasa, Manajemen Pendidikan Karakter. (Jakarta: Bumi Aksara, 2018), 31-32.

14 Asmani, Kompetensi Guru, 74-75. 
efektif adalah dengan menyediakan wahana aktualisasi sebanyak mungkin, misalnya sering mengadakan lomba, pentas seni dan lain sebagainya. Semakin banyak praktik, semakin baik dalam upaya melahirkan dan mengembangkan potensi. ${ }^{15}$

Namun pada intinya bahwa motivasi merupakan kondisi psikologis yang mendorong seseorang untuk melakukan sesuatu. Dalam kegiatan belajar, motivasi dapat dikatakan keseluruhan daya penggerak di dalam diri peserta didik yang menimbukan, menjamin kelangsungan dan memberikan arah kegiatan belajar, sehingga diharapkan tujuan dapat tercapai. Dalam kegiatan belajar, motivasi sangat diperlukan, sebab seseorang yang tidak mempunyai motivasi dalam belajar, tidak akan mungkin melakukan aktivitas belajar. ${ }^{16}$

3) Dinamisator

Selain guru berperan sebagai motivator guru juga menjadi lokomotif utama dalam menuntun peserta didiknya menuju kesuksesan. Seorang guru harus memiliki wawasan luas, kreativitas dan juga harus profesionalisme.

Menurut Jamal ma'mur asmani ada beberapa kriteria guru dinamisator yaitu sebagai berikut:

a. Kaya gagasan dan pemikiran, serta mempunyai visi yang jauh ke depan

b. Mempunyai kemampuan manajemen terstuktur, sistematis, fungsional dan profesional.

c. Mempunyai jaringan yang luas sehingga bisa melangkah secara ekspansif dan eksploratif.

d. Mempunyai kemampuan sosial dan humaniora yang bagus, sebab pendekatan persuasif-humanis-emosional lebih efektif dalam memecahkan kebuntuan daripada sekedar formalis-organisatoris-legalis.

e. Mempunyai kretivitas yang tinggi, khususnya dalam mencipta dan mencari solusi dari problem yang ada.

f. Mempunyai kematangan dalam berpolitik, antara fungsi stabilator dan dinamisator, di satu sisi menjaga stabilktas (keseimbangan), namun di sisi lain harus menggerakkan progres (kemajuan).

g. Harus mengedepankan kaderisasi dan regenerasi.

Selain itu menjadi guru dinamisator harus mempunyai kemampuan yang sinergis antara intelektual, emosional dan spiritual sehingga mampu menahan setiap serangan yang menghalangi. Sinergi tiga kemampuan ini akan menciptakan adversity quotient (kemampuan pertahanan) yang

${ }^{15}$ Asmani, Kompetensi Guru, 77-78

${ }^{16}$ Mujtahid. Pengembangan Profesi Guru, (Malang: UIN-MALIKI Press, 2011) 
membuatnya terus mendaki puncak prestasi setinggi-tingginya tanpa ada batas. Kemampuan-kemampuan tersebut menjadikan guru sebagai seorang dinamisator yang efektif produktif dalam melahirkan karya, baik pemikiran maupun sosial, yang bisa diteruskan an dikembangkan oleh kader-kader berikutnya. ${ }^{17}$

4) Evaluator

Guru harus mengevaluasi disetiap pembelajaran peserta didik yang selama ini dipakai dalam pendidikan karakter agar mengetahui meningkat atau menurunnya prestasi dan juga sikap peserta didik salah satunya bisa dilakukan melalui program pembiasaan membaca asma' ul husna.

Guru juga dikatakan sebagai evaluator, yaitu melakukan evaluasi/penilaian terhadap aktivitas yang telah dikerjakan dalam sistem sekolah. Peran ini penting karena guru sebagai pelaku utamanya dalam menentukan pilihan-pilihan serta yang ada di sekolah, baik itu menyangkut kurikulum, pengajaran, sarana-prasarana, regulasi, sasaran dan tujuan, hingga masukan dari masyarakat luas. Seorang guru harus terus menerus melakukan evaluasi baik ke dalam maupun ke luar sekolah, guna meningkatkan mutu pendidikan yang lebih baik. ${ }^{18}$

Dalam evaluasi, dibutuhkan suasana kekeluargaan yang menekankan kebersamaan, kekompakan dan kemajuan. Sehingga, kritik dan masukan positif dan kontstruktif sangat dibutuhksn. Jsngsn pernah berupaya merendahkan, melecehkan, menghina dan menurnkan derajat seseorang. Sebab, hal itu berakibat kontraproduktif dan membuat suasana menjadi tidak kondusif. Selain itu, kritik yang demikian juga bisa menjadi benih konflik, balas dendam dan konfrotansi yang merintangi kemajuan. ${ }^{19}$ Peranperan yang diterapkan oleh guru di SMPN 1 Ngoro Jombang memang tidak semua peran-peran guru dalam pendidikan karakter yang sudah ada. Hanya beberapa yang di perlukan dalam pelaksanaan program keagamaan terkhusus program pembiasaan membaca asma'ul husna.

Agar guru dapat mengembangkan pendidikan secara efektif, serta dapat meningkatkan kualitas pendidikan, khususnya dalam peningkatan pribadi peserta didik, guru perlu memiliki hal-hal berikut:

1. Menguasai dan memahami pendidikan karakter dan hubungannya dengan pembelajaran yang baik

2. Menyukai pendidikan karakter

3. Memahami peserta didik, pengalaman, kemampuan, dan prestasinya

\footnotetext{
17 Asmani, Kompetensi Guru, 80-81.

18 Mujtahid. Pengembangan Profesi, 117.

${ }^{19}$ Asmani, Kompetensi Guru, 83.
} 
4. Menggunakan metode pendidikan karakter yang bervariasi

5. Mengeliminasi bahan-bahan yang kurang berkarakter dan kurang berarti

6. Mengikuti perkembangan pendidikan karakter

7. Mempersiapkan proses pendidikan karakter secara matang

8. Mendorong peserta didiknya untuk memiliki karakter yang baik dan

9. Menghubungkan pengalaman yang lalu dengan karakter yang akan dibentuk.

\section{Karakter religius peserta didik di SMPN 1 Ngoro Jombang}

Proses pendidikan di SMPN 1 Ngoro yang notabene merupakan sekolah negeri yang bukan berlatar belakang madrasah, akan tetapi suasana religiusnya tidak kalah dengan madrasah tsanawiyah, tidak semua warga sekolahnya beragama muslim namun SMPN 1 Ngoro Jombang di sini berupaya untuk membentuk dan juga meningkatkan karakter pada peserta didik yang datang dari latar belakang yang berbeda terutama pada karakter religiusnya sehingga SMPN 1 Ngoro ini bukan hanya sekolah negeri pada umumnya tetapi berbasis madrasah hal ini sesuai dengan visi umumnya yaitu beriman, berkarya dan berprestasi, untuk mewujudkan visi tersebut sekolah mengadakan beberapa program yang sangat kental dengan keagamaan dengan harapan mampu mencetak generasi yang memiliki jiwa spiritual yang tinggi, berakhlak mulia, ketaqwaan pada Tuhan Yang Maha Esa dan mampu menerapkan programprogram di sekolah menjadi pembiasaan yang baik di kehidupan sehari-hari.

Karakter di maknai sebagai cara berfikir dan berperilaku yang khas tiap individu untuk hidup dan bekerja sama dengan baik dalam lingkup keluarga, masyarakat, bangsa dan negara. ${ }^{20}$ Sedangkan kata religius berakar dari kata religi (religion) yang artinya taat pada agama. ${ }^{21}$ Dasar religius adalah dasar

\footnotetext{
${ }_{20}$ M. Samani, \& Hariyanto. Konsep dan Model Pendidikan Karakter. (Bandung: RemajaRosdakarya. Samani \& Hariyanto, 2017), :41.

${ }^{21}$ Mulyasa, Manajemen Pendidikan Karakter, 73.
} 
yang turunkan dari ajaran agama. Urgensi dasar ini terletak pada tujuannya agar seluruh proses bahkan hasil dari pendidikan islam dapat bermakna. ${ }^{22}$

Pendidikan karakter memiliki makna lebih tinggi dari pendidikan moral, karena pendidikan karakter tidak hanya berkaitan dengan masalah benar-salah, tetapi bagaimana menanamkan kebiasaan (habit) tentang hal-hal yang baik dalam kehidupan, sehingga anak/peserta didik memiliki kesadaran, dan pemahaman yang tinggi, serta kepedulian dan komitmen untuk menerapkan kebijakan dalam kehidupan sehari-hari. Dengan demikian dapat dikatakan bahwa karakter merupakan sifat alami seseorang dalam merespons situasi secara bermoral, yang diwujudkan dalam tindakan nyata melalui perilaku baik, jujur, bertanggung jawab, hormat terhadap orang lain dan nilai-nilai karakter mulia lainnya. Dalam konteks pemikiran islam, karakter berkaitan dengan iman dan ikhsan. Hal ini sejalan dengan ungkapan Aristoteles, bahwa karakter erat kaitannya dengan "habit" atau kebiasaan yang terus menerus dipraktikan dan diamalkan. $^{23}$

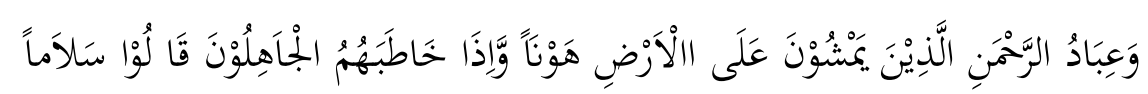

Artinya: "Adapun hamba-hamba Tuhan Yang Maha penyayang itu (adalah) orangorang yang berjalan di bumi dengan rendah hati dan apabila orang-orang bodoh menyapa mereka, (dengan kata-kata yang menghina) mereka mengucapkan, (salam)". (Al furqon: 62)

Firman Allah SWT tersebut menjelaskan jenis karakter orang-orang yang menyebarkan kasih kepada sesama manusia. Indikatornya adalah hidup tidak sombong, rendah hati, dan murah senyum meskipun orang jahil yang menyapanya, ia akan menyapanya dengan sapaan yang menyejukkan dan menyelamatkan. Warahmatullahi wabarakatuh, adalah ucapan yang mendoakan semua sesama muslim untuk memperoleh kasih sayang Allah dan keberkahanNya.

\footnotetext{
22 Nafis A. Wiyani, Pendidikan Karakter Berbasis Iman dan Taqwa. (Yogyakarta: Penerbit Teras, 2012), 54-55.

${ }^{23}$ Mulyasa, Manajemen Pendidikan Karakter, 3
} 
Pendidikan karakter bertujuan membentuk insan kamil. Kurikulum yang membangun karakter insan kamil dalam perspektif Islam memiliki ciri-ciri khusus berikut:

1. Pembinaan anak didik untuk bertauhid

2. Kurikulum harus disesuaikan dengan fitah manusia, sebagai makhluk yang memiliki keyakinan pada Tuhan.

3. Kurikulum yang disajikan merupakan hasil pengujian materi dengan landasan Al-Qur'an dan As-sunnah.

4. Mengarahkan minat dan bakat meningkatkan kemampuan akilah anak didik serta keterampilan yang akan diterapkan dalam kehidupan konkret.

5. Pembinaan akhlak anak didik, sehingga pergaulannya tidak keluar dari tuntunan islam.

6. Tidak ada kadaluarsa kurikulum karena ciri khas kurikulum islam senantiasa relevan dengan perkembangan zaman, bahkan menjadi filter kemajuan ilmu pengetahuan dan teknologi dalam penerapannya di kehidupan masyarakat.

7. Pendidikan karakter mengisyaratkan tiga macam dimensi dalam upaya mengembangkan kehidupan manusia yaitu:

1) Dimensi kehidupan duniawi yang mendorong manusia sebagai hamba Allah untuk mengembangkan dirinya dalam ilmu pengetahuan, keterampilan dan nilai-nilai islam yang mendasari kehidupan

2) Dimensi kehidupan ukhrawi yang mendorong manusia untuk mengembangkan dirinya dalam pola hubungan yang serasi dan seimbang dengan Tuhan. Dimensi inilah yang melahirkan berbagai usaha agar seluruh aktivitas manusia senantiasa sesuai dengan nilai-nilai islam

3) Dimensi hubungan antara kehidupan duniawi dan ukhrawi yang mendorong manusia untuk berusaha menjadikan dirinya sebagai hamba Allah yang utuh dan paripurna dalam bidang ilmu pengetahuan dan keterampilan, serta menjadi pendukung pelaksanaan ajaran islam. ${ }^{24}$ Sebagaimana yang telah dikonsepkan dalam meningkatkan karakter religius peserta didik di SMPN 1 Ngoro Jombang ialah dengan mengadakan program-program pembiasaan yang berbasis madrasah dan dengan menggunakan pendekatan pembiasaan, pendekatan pembiasaan tersebut dirasa cukup efektif dalam meningkatkan karakter religius peserta didik.

Berdasarkan hasil wawancara dan dokumentasi yang telah dilakukan oleh peneliti, dapat diketahui bahwa karakter religius peserta didik di SMPN 1

${ }^{24}$ Hamid \& Saebani, 41. 
Ngoro Jombang cukup efektif dan efesien. Karakter religius di SMPN 1 Ngoro Jombang yaitu mulai sebelum pembelajaran sampai dengan selesai pembelajaran dan evaluasi yang dirancang oleh para guru melalui buku monitoring. Melalui program pembiasaan membaca asma'ul husna, pembiasaan membaca Al Qur'an, pembiasaan sholat duha dan pembiasaan sholat duhur yang di dalamnya terdapat aspek pendidikan karakter religius dengan metode pembiasaan, keteladanan dan pembinaan disiplin. Menurut Mulyasa (2008) pendidikan karakter dapat dilakukan dengan berbagai model. Model tersebut antara lain: pembiasaan, keteladanan, pembinaan disiplin, hadiah dan hukuman, CTL (contectual teaching and learning), bermain peran (role playing), dan pembelajaran partisipatif (participative instruction).

1. Pembiasaan

Dari hasil observasi peneliti dapat disimpulkan bahwa upaya yang dilakukan sekolah dalam meningkatkan karakter religius peserta didik yaitu melalui program pembiasaan. Peserta didik dituntut untuk aktif mengikuti segala kegiatan pembiasaan di sekolah yang dilakukan mulai dari sebelum pembelajaran sampai selesai pembelajaran diantaranya pembiasaan membaca asma'ul husna, pembiasaan membaca Al Qur'an, pembiasaan sholat duha, pembiasaan sholat duhur berjamaa'ah. Tetapi pembiasaan ini jangan hanya terfokus pada program di sekolah tapi perlu juga adanya pembiasaan ketika di rumah karena pembiasaan merupakan cara efektif untuk meningkatkan karakter religius peserta didik.

Pembiasaan adalah sesuatu yang sengaja dilakukan secara berulangulang agar sesuatu itu dapat menjadi kebiasaan. Pembiasaan sebenarnya berintikan pengalaman, yang dibiasakan itu adalah sesuatu yang diamalkan. Pembiasaan menempatkan manusia sebagai sesuatu yang istimewa, yang dapat menghemat kekuatan, karena akan menjadi kebiasaan yang melekat dan spontan, agar kekuatan itu dapat dipergunakan untuk berbagai kegiatan dalam setiap pekerjaan dan aktivitas lainnya. Pembiasaan dalam pendidikan hendaknya dimulai sedini mungkin. Membiasakan anak shalat, lebih-lebih dilakukan secara berjama'ah itu penting. Dalam kehidupan sehari-hari pembiasaan itu merupakan hal yang penting. Karena banyak dijumpai orang berbuat dan berperilaku hanya karena kebiasaan semata-mata. Pembiasaan dapat mendorong mempercepat perilaku, dan tanpa pembiasaan hidup seseorang akan berjalan lamban, sebab sebelum melakukan sesuatu harus memikirkan terlebih dahulu apa yang akan dilakukannya.

Pendidikan melalui pembiasaan dapat dilaksanakan melalui: a). Kegiatan terprogram dalam pembelajaran dapat dilaksanakan dengan perencanaan khusus dalam kurun waktu tertentu untuk mengembangkan 
pribadi peserta didik secara individual, kelompok, atau klasikal, diantaranya dengan: 1). Biasakan peserta didik untuk bekerja sendiri, menemukan sendiri, dan mengontruksi sendiri pengetahuan, ketrampilan dan sikap baru dalam setiap pembelajaran; 2). Biasakan peserta didik untuk bertanya; 3). Biasakan peserta didik bekerja sama dan lain sebagainya. B). Kegiatan pembiasaan secara terprogram dapat dilaksanakan sebagai berikut: 1). Rutin, yaitu pembiasaan yang dilakukan secara terjadwal. Seperti: upacara, sholat berjama'ah dan pemeliharaan lingkungan; 2). Spontan, adalah pembiasaan tidak terjadwal dalam kejadian khusus, seperti: pembentukan perilaku dengan sumber salam, rajin membaca, datang tepat waktu dan lain sebagainya. ${ }^{25}$

2. Keteladanan

Berdasarkan hasil observasi peneliti, dapat disimpulkan bahwa dalam upaya meningkatkan karakter religius peserta didik melalui program pembiasaan maka didalamnya harus ada keteladanan. Dalam hal ini yang menjadi sorotan peserta didik adalah guru. Dimana guru harus bisa memberi contoh dan menjadi teladan bagi peserta didiknya dengan ikut serta dalam setiap program yang ada di sekolah. Dengan adanya sikap guru yang baik maka peserta didik akan mengikuti apa yang dilakukan oleh gurunya.

Pribadi guru memiliki andil yang sangat besar terhadap keberhasilan pendidikan, terutama dalam pendidikan karakter, yang sangat berperan dalam membentuk pribadi peserta didik. Hal ini dapat dimaklumi karena manusia merupakan makhluk yang suka mencontoh, termasuk peserta didik mencontoh pribadi gurunya dalam membentuk pribadinya. Semua itu menunjukan bahwa kompetensi personal atau kepribadian guru sangat dibutuhkan oleh peserta didik dalam proses pembentukan pribadinya. Oleh karena itu wajar, ketika orang tua mendaftarkan anaknya ke sautu seoklah akan mencari tahu siapa dulu guru-guru yang akan membimbing anaknya. Dalam pendidikan karakter pribadi guru akan menjadi teladan, diteladani atau keteladanan bagi para peserta didik.

Keteladanan guru sangat besar pengaruhnya terhadap pertumbuhan dan perkembangan pribadi para peserta didik. Keteladanan ini memiliki peran dan fungsi yang sangat penting dalam membentuk kepribadian anak guna menyiapkan dan mengembangkan Sumber Daya Manusia (SDM), serta mensejahterakan masyarakat, kemajuan negara, dan bangsa pada umumnya. Oleh karena itu, dalam mengefektifkan dan menyukseskan pendidikan karakter di sekolah, setiap guru dituntut untuk memiliki kompetensi

${ }^{25}$ Mulyasa, Manajemen Pendidikan Karakter 167-168). 
kepribadian yang memadai, bahkan kompetensi ini akan melandasi atau menjadi landasan bagi kompetensi-kompetensi lainnya, dalam hal ini, guru tidak hanya dituntut untuk mampu memaknai pembelajaran, tetapi dan yang paling penting adalah bagaimana dia menjadikan pembelajaran sebagai ajang pembentukan karakter dan perbaikan kualitas pribadi pesert didik. ${ }^{26}$

3. Pembinaan disiplin peserta didik

Berdasarkan hasil observasi peneliti maka dapat disimpulkan bahwa kedisiplinan sangat diterapkan di SMPN Ngoro. Mulai dari disiplin waktu, penampilan sampai ketika pelaksanaan kegiatan. Pentingnya menerapkan kedisiplinan sejak dini agar nantinya menjadi kebiasaan yang baik. Sehingga bukan hanya ketika di sekolah saja tetapi juga dalam kehidupan sehari-hari

Dalam rangka menyukseskan pendidikan karakter, guru harus mampu menumbuhkan disiplin peserta didik, terutama disiplin diri (self-disciplien). Guru harus mampu membantu peserta didik mengembangkan pola perilakunya, meningkatkan standar perilakunya, dan melaksanakan aturan sebagai alat untuk menegakkan disiplin. Untuk mendisiplinkan peserta didik perlu dimulai dengan prinsip yang sesuai dengan tujuan pendidikan nasional, yakni sikap demokratis, sehingga peraturan disiplin perlu berpedoman pada hal tersebut. Yakni dari, oleh dan untuk peserta didik, sedangkan guru tut wuri handayani. ${ }^{27}$

Dalam pelaksanaannya tidak semua model di terapkan hanya beberapa saja yang di butuhkan dalam kegiatan meningkatkan karakter religius melalui program-program yang ada di SMPN 1 Ngoro Jombang. Adanya program pembiasaan di SMPN 1 Ngoro sebagai bukti bahwa pendidikan karakter sangat penting terutama pendidikan karakter religius. Berdasarkan hasil observasi dalam pelaksanaan pembiasaan membaca asma'ul husna tertanam beberapa nilai-nilai karakter pada peserta didik: religius, disiplin, tanggungjawab, berakhlakul karimah dan mandiri.

Berdasarkan kajian berbagai nilai agama, norma sosial, peraturan atau hukum, etika akademik, dan prinsip-prinsip HAM, telah teridentifikasi butirbutir nilai yang dikelompokkan menjadi lima, nilai utama yaitu nilai-nilai perilaku manusia dalam hubungannya dengan Tuhan Yang Maha Esa, diri sendiri, sesama manusia, lingkungan dan kebangsaan. Berikut adalah daftar dan deskripsi ringkas nilai-nilai utama yang dimaksud:

1) Nilai Karakter dalam Hubungannya dengan Tuhan

\footnotetext{
${ }^{26}$ Mulyasa, Manajemen ..., 169-170

27 Mulyasa, Manajemen Pendidikan Karakter..., 172-173.
} 
Nilai ini bersifat religius. Dengan kata lain pikiran, perkataan, dan tindakan seseorang diupayakan selalu berdasarkan pada nilai-nilai ketuhanan dan atau ajaran agama

2) Nilai Karakter Hubungannya dengan Diri Sendiri

Ada beberapa nilai karakter yang berhubungan dengan diri sendiri. Berikut beberapa nilai karakter tersebut.

a) Jujur. Jujur atau kejujuran merupakan perilaku yang ada didasarkan pada upaya menjadikan diri sebagai orang yang selalu dapat dipercaya. Hal ini diwujudkan dalam hal perkataan, tindakan, dan pekerjaan, baik terhadap diri sendiri maupun pada pihak lain.Kejujuran merupakan perilaku yang didasarkan pada upaya menjadikan diri sebagai orang yang selalu dapat dipercaya, baik terhadap diri sendiri maupun oranglain.

b) Bertanggung Jawab. Ini merupakan sikap dan perilaku seseorang untuk melaksanakan tugas dan kewajibannya, sebagaimana yang seharusnya ia lakukan terhadap diri sendiri, masyarakat, lingkungan (alam, sosial, dan budaya), negara dan Tuhan Yang Maha Esa.

c) Bergaya hidup sehat. Segala upaya untuk menerapkan kebiasaan yang baik dalam menciptakan hidup yang sehat dan menghindarkan kebiasaan buruk yang dapat mengganggu kesehatan

d) Disiplin. Tindakan yang menunjukkan perilaku tertib dan patuh pada berbagai ketentuan dan peraturan.

e) Kerja keras

Perilaku yang menunjukkan upaya sungguh-sungguh dalam mengatasi berbagai hambat guna menyelesaikan tugas (belajar/pekerjaan) dengan sebaik-baiknya.

f) Percaya diri. Sikap yakin akan kemampuan diri sendiri terhadap pemenuhan tercapai setiap keinginan dan harapannya.

g) Berjiwa Wirausaha. Sikap dan perilaku yang mandiri dan pandai atau berbakat mengenali produk baru, menentukan cara produksi baru, menyusun operasi untuk pengadaan produk baru, memasarkannya, serta mengatur permodalan operasinya.

h) Berfikir Logis, Kritis, Kreatif, dan inovatif. Berpikir dan melakukan sesuatu secara nyata atau logika untuk menghasilkan cara atau hasil baru dan mutakhir dari sesuatu yang telah dimiliki.

i) Mandiri. Sikap dan perilaku yang tidak mudah bergantung pada orang lain dalam menyelesaikan tugas-tugas. 
j) Ingin Tahu. Sikap dan tindakan yang selalu berupaya untuk mengetahui lebih mendalam dan meluas dari sesuatu yang dipelajari, dilihat, dan didengar.

k) Cinta Ilmu. Cara berfikir, bersikap, dan berbuat yang menunjukkan kesetiaan, kepedulian, dan penghargaan yang tinggi terhadap pengetahuan.

3) Nilai Karakter Hubungan dengan sesama

a) Sadar hak dan kewajiban diri dan orang lain

Sikap tahu dan mengerti serta melaksanakan sesuatu yang menjadi milik atau hak diri sendiri dan oranglain, serta tugas atau kewajiban diri sendiri dan oranglain.

b) Patuh pada aturan-aturan sosial

Sikap menurut dan taat terhadap aturan-aturan berkenan dengan masyarakat dan kepentingan umum.

c) Menghargai karya dan prestasi oranglain

Menghargai karya dan prestasi oranglain merupakan sikap dan tindakan yang mendorong diri untuk menghasilkan sesuatu yang berguna bagi masyarakat. Serta, mengakui dan menghormati keberhasilan oranglain.

d) Santun

Santun merupakan sifat yang yang halus dan baik dari sudut pandang tata bahasa maupin tata perilakunya kepada semua orang.

e) Demokratis

Cara berpikir, bersikap, dan bertindak yang menilai sama hak dan kewajiban diri sendiri dan oranglain.

4) Nilai karakter hubungannya dengan lingkungan

Hal ini berkenaan dengan kepedulian terhadap sosial dan lingkungan. Nilai karakter tersebut berupa sikap dan tindakan yang selalu berupaya mencegah kerusakan pada lingkungan alam di sekitarnya. Selain itu, mengembangkan upaya-upaya untuk memperbaiki kerusakan alam yang sudah terjadi dan selalu ingin memberi bantuan oranglain dan masyarakat yang membutuhkan.

5) Nilai kebangsaan

Artinya, cara berfikir, bertindak, dan wawasan yang menempatkan kepentingan bangsa dan negara di atas kepentingan diri dan kelompok.

a) Nasionalis

Cara berfikir, bertindak, dan berbuat yang menunjukkan kesetiaan, kepedulian, dan penghargaan yang tinggi terhadap bahasa, lingkungan fisik, sosial, budaya, ekonomi, dan pilitik bangsanya. 
b) Sikap memberikan respek atau hormat terhadap berbagai macam hal, baik yang berbentuk fisik, sifat, adat, budaya, suku, maupun agama.

Nilai-nilai karakter tersebut sangatlah agung, betapa hebatnya kaderkader muda indonesia yang mempunyai nilai-nilai tersebut. Tentu, dibutuhkan perjuangan serius dan kolektif dari seluruh anak bangsa karena nilai-nilai karakter itu membutuhkan partisipasi aktif dari seluru elemen bangsa, mulai keluarga, lembaga pendidikan, dunia usaha, pemerintah, wakil rakyat, media informasi, dan lain sebagainya.

\section{Kesimpulan}

Guru memiliki peran penting dalam sebuah lembaga pendidikan dimana seorang guru tidak hanya bertugas memberikan materi di kelas lebih dari itu guru memiliki tugas penting dalam pendidikan karakter peserta didik terutama karakter religius. Di SMPN 1 Ngoro guru bekerjasama dalam upaya meningkatkan karakter religius peserta didik yaitu dengan melalui program-program berbasis madrasah yang ada di sekolah. Dapat disimpulkan peran guru dalam pendidikan karakter di SMPN 1 Ngoro Jombang yaitu: Teladan, Motivator, Dinamisator, Evaluator.

Karakter religius peserta didik di SMPN 1 Ngoro Jombang. Karakter religius sudah tercermin pada peserta didik yaitu dengan adanya sikap toleransi antar agama, saling menghormati dan juga disiplin dalam mengikuti program-program yang ada di SMPN 1 Ngoro Jombang. dan nilai-nilai yang ditanamkan di SMPN 1 Ngoro Jombang antara lain: religius, toleransi, disiplin, tanggungjawab, berakhlakul karimah, dan mandiri. 
Nurul Lailiyah, Rofiqotul Hasanah

Peningkatan Karakter Religius...

\section{DAFTAR PUSTAKA}

Anas, Salahudin dan Irwanto A. PendidikanKarakter Berbasis Agama dan Budaya Bangsa. Bandung: Pustaka Setia, 2013.

Desmita. Psikologi Perkembangan Peserta Didik. Bandung: PT. Remaja Rosdakarya, 2012.

Hawi, Asmani Kompetensi Guru Pendidikan Agama Islam. Jakarta: Rajawali Pers, 2014

Mujtahid. Pengembangan Profesi Guru. Malang: UIN-MALIKI Press, 2011

Mulyasa, Manajemen Pendidikan Karakter. Jakarta: Bumi Aksara, 2018

Samani M., \& Hariyanto. Konsep dan Model Pendidikan Karakter. Bandung: Remaja Rosdakarya, 2017.

Sardiman, A.M..Interaksi dan Motivasi Belajar Mengajar. Jakarta: PT Raja Grafindo Persada. 2008

Undang-Undang RI No. 20 Tahun 2003 tentang Sistem Pendidikan Nasional

Wiyani, N. A. Pendidikan Karakter Berbasis Iman dan Taqwa. Yogyakarta: Penerbit Teras, 2011. 